\title{
FT-IR SPECTROSCOPIC ANALYSIS OF POTSHERDS EXCAVATED FROM THE FIRST SETTLEMENT LAYER OF KURIKI MOUND, TURKEY
}

\author{
MURAT BAYAZIT \\ Ceramics, Batman University, Central Campus, \\ Batman, 72100, Turkey \\ m.bayazit@hotmail.com \\ ISKENDER ISIK \\ Materials and Ceramics Engineering, Dumlupinar University,Evliya Celebi Campus, \\ Tavsanlı Road, Kütahya,43100, Turkey \\ is4326@gmail.com \\ SEDAT CERECI \\ Cinema and Television, Batman University, Central Campus, Batman, 72100, Turkey \\ s.cereci@gmail.com \\ ALI ISSI \\ Materials and Ceramics Engineering, Dumlupinar University,Evliya Celebi Campus, \\ Tavsanlı Road, Kütahya,43100, Turkey \\ aliissi@hotmail.com \\ ELIF GENC \\ Archaeology, Cukurova University, Balcali, \\ Adana,01330, Turkey \\ egenc@cu.edu.tr
}

\begin{abstract}
The region covering Southeastern Anatolia takes place in upper Mesopotamia, so it has numerous cultural heritages due to its witness to various social movements of different civilizations in ancient times. Kuruki Mound is located on the junction point of Tigris River and Batman Creek, near Oymatas village which is almost $15 \mathrm{~km}$ to Batman, Turkey. The mound is dated back to Late Chalcolithic. Archaeological excavations are carried out on two hills named as "Kuriki Mound-1" and "Kuriki Mound-2" in which 4-layer and 2-layer settlements have been revealed, respectively. This region will be left under the water by the reservoir lake of Ilısu Dam when its construction is completed. Thus, characterization of ancient materials such as potsherds, metals and skeleton ruins should be rapidly done. In this study, 12 potsherds excavated from Layer-1 (the first settlement layer after the surface) in Kuriki Mound-2 were investigated by FT-IR spectrometry. Energy dispersive X-ray fluorescence (EDXRF) and X-ray diffraction (XRD) analyses were used as complementary techniques in order to expose chemical and mineralogical/phase contents, respectively. Obtained results showed that the potteries have been produced with calcareous clays and they include moderate amounts of $\mathrm{MgO}, \mathrm{K} 2 \mathrm{O}, \mathrm{Na} 2 \mathrm{O}$ and $\mathrm{Fe} 2 \mathrm{O} 3$ in this context. Additionally, high temperature phases have also been detected with XRD analyses in some samples.
\end{abstract}

Keywords: FT-IR spectroscopy; Archaeometry; Characterization; Kuriki Mound (Turkey). 


\section{Introduction}

Southeastern Anatolia has witnessed crucial changes, innovations and developments throughout the history mostly due to its location in upper Mesopotamia where is created by two important rivers; Tigris and Euphrates. As a consequence of this, there are numerous ancient settlements and materials waiting to be investigated. The most remarkable materials of such relics are potsherds which are the most common artifacts encountered in archaeological excavations, hence archaeologists and others who are interested in archaeometry have a special attention for pottery fragments [1].

In archaeometric researches, there are many various characterization methods applied on especially ancient ceramic materials in order to investigate the specific characteristics of their structural features. In this sense, some of the conventional characterization techniques are X-ray fluorescence (XRF) and X-ray diffraction (XRD), scanning electron microscopy (SEM) with wavelength or energy dispersive X-ray spectrometry (WDX/EDX), Mossbauer, Fourier transform infrared (FTIR) and Raman Spectroscopy [2-8]. These techniques provide identification of mineralogical/phase composition which initially depends on raw materials, production technologies and burials conditions. Additionally, since the minerals are evidences of formation and decomposition of solid phases occurred during firing, duration of firing, maximum temperature reached and atmospheric conditions of firing process are the significant parameters in estimating and considering the changes in ceramic fabrics which will then enlighten the secrets about ancient samples $[9,10]$.

While investigating ancient artifacts, one of the most important subjects is mineral identification. In this sense, minerals which are expected to be defined in archaeological ceramic residues can be considered in three stages, namely; "primary minerals" that are already present in used raw materials, "secondary minerals" that occur during use and burial of historical findings, and "firing minerals" that are formed during firing process [10-13]. This approach would be directive to reach proper results in terms of estimating provenance and production techniques of potsherd samples uncovered from archaeological excavations. The aim of this study is to characterize ancient potteries

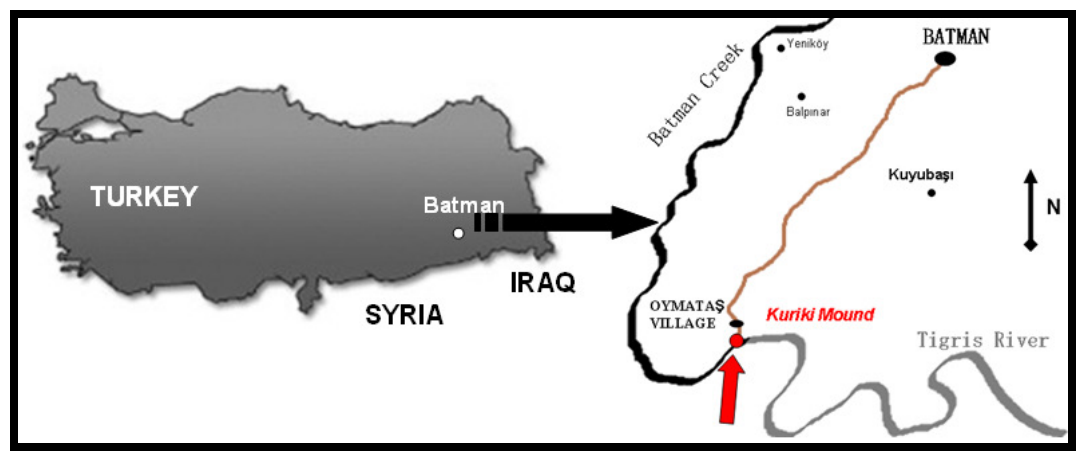

Fig. 1. Location of Kuriki Mound (almost $15 \mathrm{~km}$ to Batman city). 
found in the first settlement layer encountered in archaeological excavations in Kuriki Mound-2 (Turkey) (Fig.1) by using Fourier transform infrared (FTIR), X-ray fluorescence (XRF) and X-ray diffraction (XRD). The last two analyses are used as complementary techniques to define chemical and mineralogical/phase contents, respectively. After gathering all the results obtained by these techniques, it would be possible to reveal production technology (especially firing techniques) and mineralogical components of potsherds of the mound which is dated back to Late Chalcolithic (approximately from half of the $4^{\text {th }}$ millennium BCE).

\section{Metarials and Methods}

\subsection{Archaeological Samples}

Twelve potsherds from Kuriki Mound-2 which belong to the first settlement (the layer after surface) were selected for the study. Images of potteries are given in Fig. 2. These samples have the colors of buff, brown, black and red. Some of them have traces of ornamentation including floral or figurative decorations. Types of the samples are rim, edge, neck and handle of the ceramic wares.

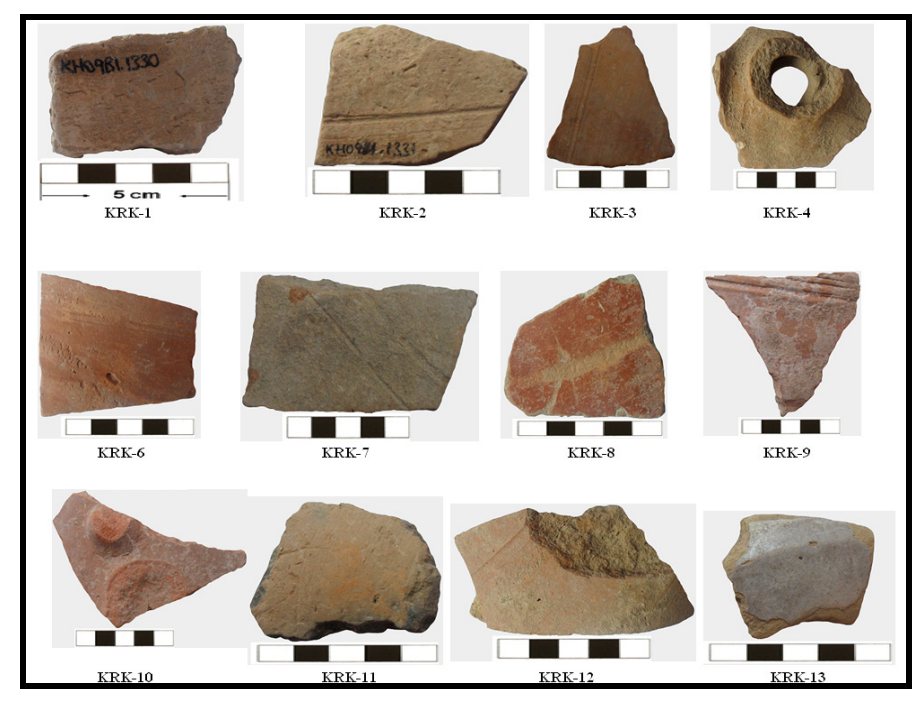

Fig. 2. Images of potsherds

\subsection{Methods}

The samples were ground in an agate mortar into fine powder for FT-IR, XRD and EDXRF analysis. Spectro X-Lab 2000 instrument was used for chemical analysis of major and minor elements. Tablets consisting of $4 \mathrm{gr}$ sample powder and $0.9 \mathrm{gr}$ binder (HWC) were prepared by pressing process with a pressure value of $10^{5} \mathrm{~N}$. Rigaku Miniflex powder diffractometer with $\mathrm{Cu} \mathrm{K} \alpha$ radiation and Jade software were used for 
the mineralogical analysis. The patterns of XRD were obtained by scanning $2-70^{\circ} 2 \theta$, with a goniometer speed of $2 \%$ min. Perkin Elmer Spectrum-100 (ATR) FT-IR spectrometer (with $4 \mathrm{~cm}^{-1}$ resolution) possessing $\mathrm{KBr}$ beamsplitter was used to collect IR spectra of the samples. The scan range was $4000-400 \mathrm{~cm}^{-1}$ and wave number of IR-Laser was $15798.00 \mathrm{~cm}^{-1}$.

\section{Results and Discussions}

\subsection{EDXRF and XRD Results}

When EDXRF results are examined from Table.1, $\mathrm{CaO}$ quantities change between 8.97 and $43.2 \mathrm{wt} . \%$. So, this indicates that the potteries may have been produced by using calcareous clays. This is also related with burial duration and conditions, because secondary calcite may occur in ancient potteries due to recarbonation of lime (depending on post-burial deposition processes) [14]. $\mathrm{MgO}$ and $\mathrm{K}_{2} \mathrm{O}$ quantities are in moderate range of 3.43-6.47 and 1.27-3.25 wt.\%, respectively. $\mathrm{Na}_{2} \mathrm{O}$ quantities change between 0.1 and 2.67 wt.\%. Iron oxide $\left(\mathrm{Fe}_{2} \mathrm{O}_{3}\right)$ quantities change between from 5.05 to 9.13 wt.\%. In context of mineral diversity; Quartz $\left(\mathrm{SiO}_{2}\right)$, calcite $\left(\mathrm{CaCaO}_{3}\right)$, dolomite $\left[(\mathrm{Ca}, \mathrm{Mg})\left(\mathrm{CO}_{3}\right)_{2}\right]$, feldspars [K-feldspar (KAlSi3O8), and plagioclase [(Na,Ca)AlSi3O8]], gehlenite $\left(\mathrm{Ca}_{2} \mathrm{Al}\right.$ $\left.\left[\mathrm{AlSiO}_{7}\right]\right)$, illite $\left(\mathrm{K}, \mathrm{H}_{3} \mathrm{O}\right)(\mathrm{Al}, \mathrm{Mg}, \mathrm{Fe})_{2}(\mathrm{Si}, \mathrm{Al})_{4} \mathrm{O}_{10}\left[(\mathrm{OH})_{2},\left(\mathrm{H}_{2} \mathrm{O}\right)\right]$, muscovite $\left(\mathrm{KAl}_{2}\right.$ $\left.\left(\mathrm{AlSi}_{3} \mathrm{O}_{10}\right)(\mathrm{F}, \mathrm{OH})_{2}\right)$, augite $\left[\mathrm{Ca}(\mathrm{Mg}, \mathrm{Fe}) \mathrm{Si}_{2} \mathrm{O}_{6}\right]$ were identified from XRD spectra of potsherds (Table.2).

Table 1. EDXRF results of potsherds (K represents KRK; i.e. K1=KRK1).

\begin{tabular}{|c|c|c|c|c|c|c|c|c|c|c|c|c|}
\hline \multirow{2}{*}{$\begin{array}{l}\text { Oxide } \\
\text { (wt.\%) }\end{array}$} & \multicolumn{12}{|c|}{ Sample Code } \\
\hline & $\mathrm{K} 1$ & $\mathrm{~K} 2$ & $\mathrm{~K} 3$ & K4 & K6 & K7 & K8 & K9 & K10 & K11 & K12 & K13 \\
\hline $\mathrm{SiO}_{2}$ & 42 & 51,8 & 56,5 & 57,3 & 56,3 & 60,2 & 54,7 & 56,3 & 54,4 & 56,7 & 36,7 & 52,3 \\
\hline $\mathrm{Al}_{2} \mathrm{O}_{3}$ & 9,95 & 13,5 & 15,2 & 13,6 & 15,3 & 14,6 & 13,8 & 15,4 & 15 & 13,5 & 8,53 & 11,4 \\
\hline $\mathrm{CaO}$ & 32,5 & 19,5 & 9,13 & 12,2 & 9,49 & 8,97 & 12,6 & 9,11 & 9,43 & 12,4 & 43,2 & 19 \\
\hline $\mathrm{Fe}_{2} \mathrm{O}_{3}$ & 5,67 & 7,99 & 8,91 & 8,64 & 8,97 & 7,78 & 7,99 & 9,13 & 8,7 & 8,19 & 5,05 & 7,49 \\
\hline $\mathrm{K}_{2} \mathrm{O}$ & 1,89 & 2,04 & 3,25 & 2,35 & 3,07 & 2,57 & 2,55 & 3,1 & 2,94 & 2,77 & 1,27 & 1,7 \\
\hline $\mathrm{MgO}$ & 6,47 & 3,78 & 5,31 & 3,82 & 5,31 & 4,37 & 4,59 & 5,33 & 5,62 & 4,29 & 3,43 & 6,28 \\
\hline $\mathrm{Na}_{2} \mathrm{O}$ & 0,12 & 0,11 & 0,12 & 0,12 & 0,1 & 0,12 & 2,23 & 0,11 & 2,67 & 0,13 & 0,66 & 0,12 \\
\hline $\mathrm{P}_{2} \mathrm{O}_{5}$ & 0,42 & 0,28 & 0,29 & 0,51 & 0,26 & 0,24 & 0,3 & 0,23 & 0,19 & 0,42 & 0,21 & 0,2 \\
\hline $\mathrm{SO}_{3}$ & 0,17 & 0,09 & 0,22 & 0,12 & 0,15 & 0,1 & 0,09 & 0,15 & 0,13 & 0,35 & 0,24 & 0,47 \\
\hline $\mathrm{Cl}$ & 0,03 & 0,02 & 0,07 & 0,15 & 0,03 & 0,07 & 0,03 & 0,07 & 0,02 & 0,06 & 0,04 & 0,2 \\
\hline $\mathrm{TiO}_{2}$ & 0,64 & 0,73 & 0,82 & 1,11 & 0,84 & 0,81 & 0,96 & 0,86 & 0,82 & 0,98 & 0,51 & 0,7 \\
\hline $\mathrm{V}_{2} \mathrm{O}_{5}$ & 0,01 & 0,02 & 0,02 & 0,02 & 0,02 & 0,02 & 0,02 & 0,02 & 0,02 & 0,02 & - & 0,02 \\
\hline $\mathrm{MnO}$ & 0,11 & 0,12 & 0,13 & 0,13 & 0,13 & 0,12 & 0,12 & 0,13 & 0,12 & 0,13 & 0,07 & 0,13 \\
\hline
\end{tabular}


Table 2. XRD results of samples.

\begin{tabular}{cc}
\hline Sample Code & Minerals/Phases \\
\hline KRK-1 & Quartz, Calcite, Dolomite, Feldspar, Plagioclase, Illıte/Muscovite \\
KRK-2 & Quartz, Gehlenite, Feldspar, Plagioclase \\
KRK-3 & Quartz, Calcite, Feldspar, Plagioclase, Illıte/Muscovite \\
KRK-4 & Quartz, Calcite, Feldspar, Plagioclase, Illıte/Muscovite \\
KRK-6 & Quartz, Calcite, Feldspar, Plagioclase, Illıte/Muscovite \\
KRK-7 & Quartz, Calcite, Feldspar, Plagioclase, Illıte/Muscovite \\
KRK-8 & Quartz, Calcite, Feldspar, Plagioclase, Illıte/Muscovite \\
KRK-9 & Quartz, Calcite, Feldspar, Plagioclase, Illıte/Muscovite \\
KRK-10 & Quartz, Calcite, Feldspar, Plagioclase, Illıte/Muscovite \\
KRK-11 & Quartz, Calcite, Feldspar, Plagioclase, Illıte/Muscovite \\
KRK-12 & Quartz, Calcite, Illıte/Muscovite \\
KRK-13 & Quartz, Augite, Feldspar, Plagioclase \\
\hline
\end{tabular}

\subsection{FT-IR Results}

FT-IR analyses were carried out in range of 4000-400 $\mathrm{cm}^{-1}$. Results are given between 1800 and $400 \mathrm{~cm}^{-1}$, because this range is the finger-print area indicating the required information for archaeometric evaluations. FT-IR spectra $\left(1800-400 \mathrm{~cm}^{-1}\right)$ of KRK-1, KRK-2, KRK-12 and KRK-13 (selected representative potsherd samples) are given in Fig. 3-6, respectively. These specimens have been chosen according to diversity of their XRD phases.

The spectrum of KRK-1 indicates to quartz $\left(776 \mathrm{~cm}^{-1}\right)$, calcite $\left(873 \mathrm{~cm}^{-1}\right.$ and $\left.711 \mathrm{~cm}^{-1}\right)$, calcite/dolomite $\left(1433 \mathrm{~cm}^{-1}\right)$, illite/muscovite $\left(456 \mathrm{~cm}^{-1}\right)$ and muscovite $\left(551 \mathrm{~cm}^{-1}\right.$ and $1021 \mathrm{~cm}^{-1}$ ) [10, 15-19] (Fig. 3). XRF analysis of KRK-1 revealed moderate amounts of $\mathrm{SiO}_{2}, \mathrm{Al}_{2} \mathrm{O}_{3}$ and $\mathrm{Fe}_{2} \mathrm{O}_{3}$, and high amount of $\mathrm{CaO}$, so these results have been

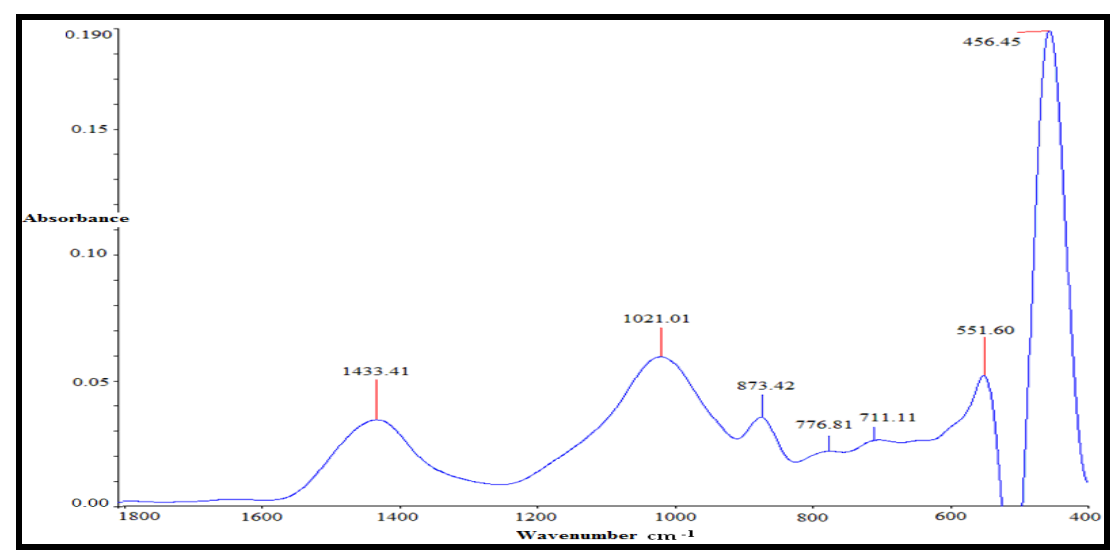

Fig. 3. FT-IR spectra of KRK-1 (\% Absorbance). 
related with FT-IR results. Additionally, XRD pattern of KRK-1 has also revealed the presence of calcite, dolomite, quartz and illite/muscovite. Consequently, absence of high temperature phases and presence of calcite and illite/muscovite allow us to estimate the firing temperature not higher than $600-850^{\circ} \mathrm{C}$, because structural decomposition of calcite and dolomite is completed at this temperature range [14, 20, 21].

According to FT-IR results of KRK-2 (Fig. 4); the most obvious peaks belong to quartz $\left(776 \mathrm{~cm}^{-1}\right.$ and $\left.693 \mathrm{~cm}^{-1}\right)$ [10, 15-19]. In accordance with the references, spectrum of KRK-2 indicates to ankerite/huntite $\left(1453 \mathrm{~cm}^{-1}\right)$, kaolinite $\left(1001\right.$ and $\left.914 \mathrm{~cm}^{-1}\right)$, illite/oligoclase $\left(1001 \mathrm{~cm}^{-1}\right)$, albite $\left(600 \mathrm{~cm}^{-1}\right)$, magnetite $\left(558 \mathrm{~cm}^{-1}\right)$, muscovite/anorthite $\left(484 \mathrm{~cm}^{-1}\right)$ [10, 15-19]. But, these results are considered by only characteristic band ranges of the minerals that take place in literature. Thus, they should be interpreted with contribution of chemical and mineralogical analysis. In this sense, as the XRD pattern of this pottery points to existence of quartz, gehlenite, feldspar and plagioclase minerals; $1453 \mathrm{~cm}^{-1}$ is likely to indicate to presence of trace amounts of $\mathrm{MgCO}_{3}$ and $\mathrm{CaCO}_{3}$, because ankerite and huntite are related with formation/decomposition reactions of these carbonates, and gehlenite is formed at $850^{\circ} \mathrm{C}$ with the reaction of $\mathrm{CaO}$ and illite structure [22]. Bands at $1001 \mathrm{~cm}^{-1}\left(600 \mathrm{~cm}^{-1}, 484 \mathrm{~cm}^{-1}\right)$ and $914 \mathrm{~cm}^{-1}$ are considered as signs of feldspar and aluminosilicates, respectively [19, 23].

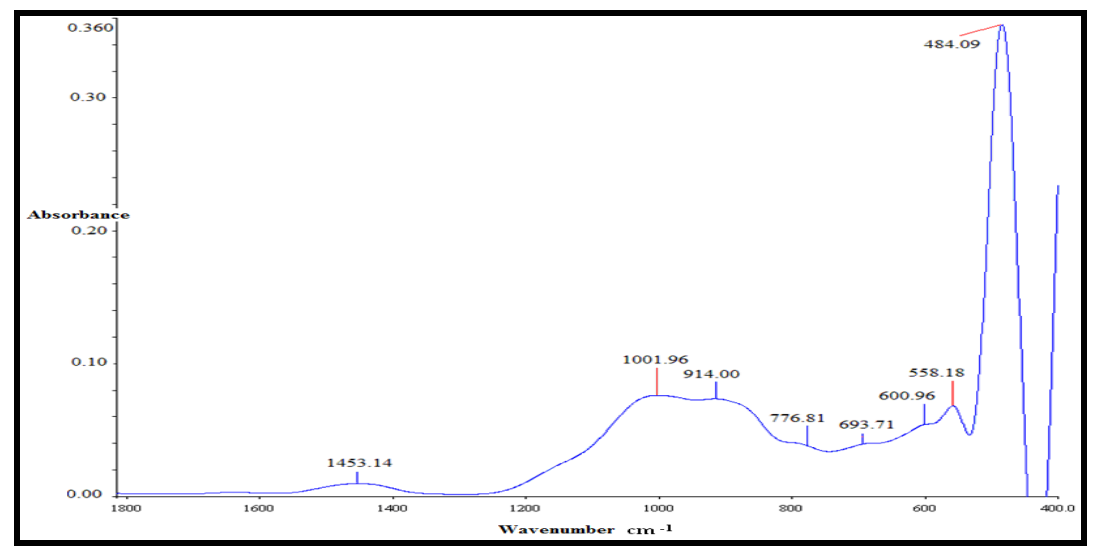

Fig. 4. FT-IR spectra of KRK-2 (\% Absorbance).

FT-IR spectrum of KRK-12 (Fig. 5) is dominated with calcite bands $\left(1426 \mathrm{~cm}^{-1}\right.$, $\left.872 \mathrm{~cm}^{-1}, 703 \mathrm{~cm}^{-1}\right)$ [15, 16] (Fig. 5). The results also include quartz $\left(780 \mathrm{~cm}^{-1}\right)$, illite/muscovite $\left(496 \mathrm{~cm}^{-1}\right.$ and $1021 \mathrm{~cm}^{-1}$, respectively), albite $\left(645 \mathrm{~cm}^{-1}, 602 \mathrm{~cm}^{-1}\right.$ and $\left.454 \mathrm{~cm}^{-1}\right)$ and magnetite $\left(559 \mathrm{~cm}^{-1}\right)$ [10, 15-19]. XRD pattern of KRK-12 approves the existence of high amount of $\mathrm{CaO}$ and chemical analysis of the potsherd also shows that the highest amount of $\mathrm{CaO}$ takes place in this specimen. Consequently, all results of these characterization techniques have suggested that this pottery has been produced by calcareous clay and this raw material may include low amount of feldspar/plagioclase and illite/muscovite. 


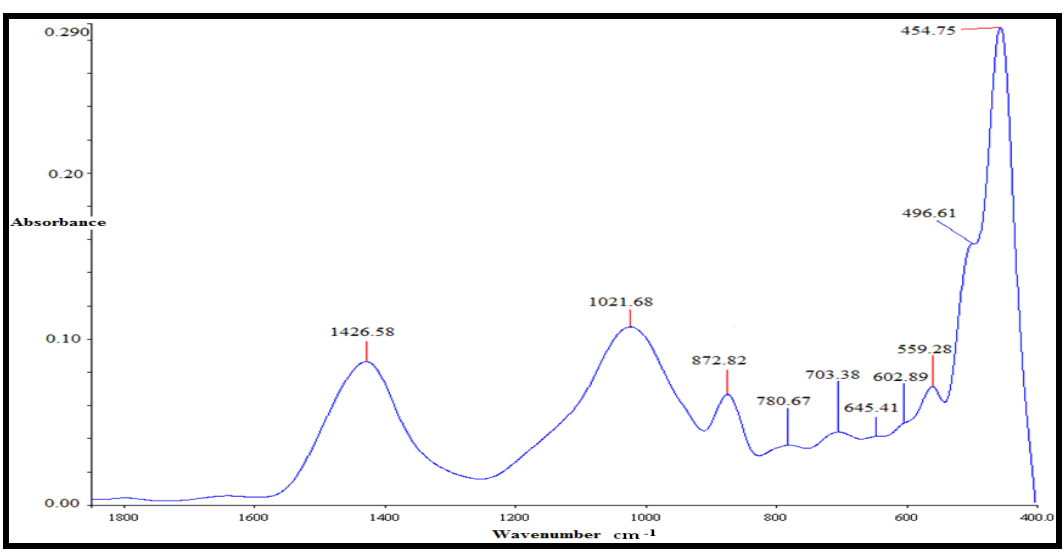

Fig. 5. FT-IR spectra of KRK-12 (\% Absorbance).

The infrared spectrum of KRK-13 is given in Fig.6. It indicates to calcite $\left(1429 \mathrm{~cm}^{-1}\right.$ and $\left.874 \mathrm{~cm}^{-1}\right)$, feldspar/plagioclase $\left(1029 \mathrm{~cm}^{-1}\right.$ and $\left.540 \mathrm{~cm}^{-1}\right)$, pyroxene (diopside: $962 \mathrm{~cm}^{-1}$ and $\left.626 \mathrm{~cm}^{-1}\right)$ and kaolinite/hematite $\left(540 \mathrm{~cm}^{-1}\right)$ [10, 15-19, 24]. XRD pattern of KRK-13 clearly shows the presence of augite, but in FT-IR spectrum, due to absence of any band reference for augite in literature, it is not possible to consider this mineral through infrared spectrum. Nevertheless, bands at $962 \mathrm{~cm}^{-1}$ and $626 \mathrm{~cm}^{-1}$ in the spectrum may be attributed to existence of augite which is another member of pyroxenes. But, this estimation may be accurate after gathering chemical and mineralogical analyses with infrared spectra. As a result of these data; sintering temperature of this ceramic sample is likely to be at least $800-900^{\circ} \mathrm{C}$ at which augite occurs with the reaction of dolomite and quartz [25].

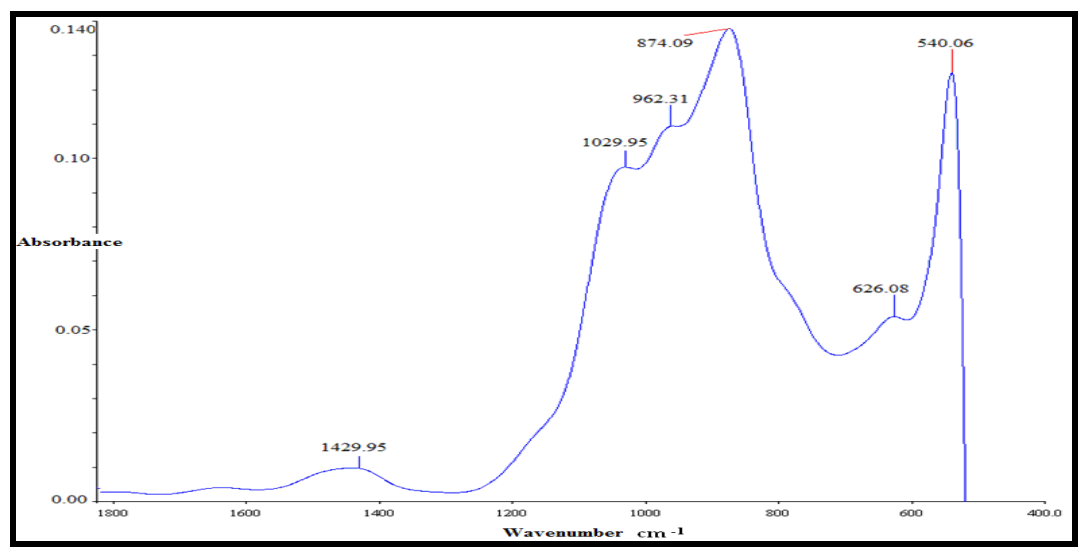

Fig. 6. FT-IR spectra of KRK-13 (\% Absorbance). 


\section{Conclusions}

This study, in which infrared spectroscopy is used together with XRD and EDXRF to characterize the samples of ancient potsherds found in the first archaeological layer of Kuriki Mound (Batman) Turkey, gives the opportunity to determine technological conditions of pottery production in the region in ancient times. The obtained results indicate that potsherds from the first archaeological layer of Kuriki Mound-2 were primarily produced with clay deposits rich in calcareous materials. Mineralogical compositions of the potsherds suggest that potteries should have been exposed to different firing temperatures during sintering process. Presence of gehlenite (in KRK-2) and augite (in KRK-13) allows us to make an interpretation that the firing temperature of these two samples should not be less than $800-850^{\circ} \mathrm{C}$ and $800-900^{\circ} \mathrm{C}$, respectively, due to formation conditions of aforementioned high-temperature phases. Firing temperature of other potteries should not be higher than $650-800^{\circ} \mathrm{C}$ due to presence of mainly calcite and illite/muscovite minerals. Although any ceramic kiln has not been recovered in the excavation area so far, it is not exactly precise that there is not a firing place in the settlement layers, because reconnaissance studies are still ongoing in the region.

Except from KRK-2 and KRK-13, other ten potsherd samples mainly include quartz and calcite together, and KRK-12 is dominated with the highest calcite content. All these information have also been detected by infrared spectroscopy by comparing characteristic band ranges of the minerals. This provide us to draw a conclusion that people have used calcareous clays as their raw materials, since this type of materials could provide them the opportunity of keeping shape of the product [26] after forming process and were abundant in the region.

\section{Acknowledgments}

This study has been supported by Batman University, Scientific Research Projects Department, Turkey. (Project code number: BTUBAP-2011-GSF-3).

\section{References}

1. R. Ravisankar, S. Kiruba, C. Shamira, A. Naseerutheen, P.D. Balaji, M. Seran, Microchem. J. 99, 370-375 (2011).

2. J. Striova, C. Lofrumento, A. Zoppi, E.M. Castellucci, J. Raman Spectrosc. 37, 1139-1145 (2006).

3. Y. Leon, C. Lofrumento, A. Zoppi, R. Carles, E.M. Castellucci, P. Sciau, J. Raman Spectrosc. 41, 1260-1265 (2010).

4. P. Mirti, X-Ray Spectrom. 29, 63-72 (2000).

5. S.R. Bertolino, V.G. Josa, A.C. Carreras, A. Laguens, G. de la Fuente, J.A. Riveros, X-Ray Spectrom. 38, 95-102 (2009).

6. A. Mangone, L.C. Giannossa, G. Colafemmina, R. Laviano, A. Traini, Microchem. J. 92, 97102 (2009).

7. G. Qin and S. Li, Hyperfine Interactions, 70, 1045-1048 (1992).

8. U. Wagner, R. Gebhard, W. Hausler, T. Hutzelmann, J. Riederer, I. Shimada, J. Sosa, F.E. Hyperfine Interactions, 122, 163-170 (1999). 
9. P.M. Rice, Pottery analysis - A sourcebook, (The University of Chicago Press, Chicago, 1987).

10. G.E. De Benedetto, R. Laviano, L. Sabbatini, P.G. Zambonin, Journal of Cultural Heritage, 3, 177-186 (2002).

11. M. Maggetti, British Museum Occasional Paper, 19, 33-49 (1981).

12. R.B. Heimann and M. Maggetti, British Museum Occasional Paper, 19, 163-177 (1981).

13. A. Ciancio, A. Dell' Anna and R. Laviano, Indagini chimicomineralogiche su ceramica a pasta grigia proveniente dalla Puglia centrale, Ceramica Romana e Archeometria: Lo Stato Delgi Studi, Edizioni all'insegna del Giglio, Firenze, 261-276 (1994).

14. C. Papachristodoulou, A. Oikonomou, K. Ioannides and K. Gravani, Anal. Chim. Acta, 573, 347-353 (2006).

15. K. Nakamoto, Infrared Spectra of Inorganic and Coordination Compounds, (WileyInterscience, London, 1970).

16. J.A. Gadsden, Infrared Spectra of Minerals and Related Inorganic Compounds, (Butterworth \& Co Publishers, London, 1975).

17. L.M. Shillito, M.J. Almond, K. Wicks, L.-J.R. Marshall and W. Matthews, Spectrochim. Acta, A 72, 120 (2009).

18. P. Maravelaki-Kalaitzaki and N. Kallithrakas-Kontos, Analytica Chimica Acta, 497, 209-225 (2003).

19. G. Kurap, S. Akyuz, T. Akyuz, S. Basaran and B. Cakan, Journal of Molecular Structure, 976, 161-167 (2010).

20. L. Maritan, C. Mazzoli, L. Nodari and U. Russo, Applied Clay Science, 29, 31-44 (2005).

21. S. Shoval, Optical Materials, 24, 117-122 (2003).

22. G. Cultrone, C. Rodriguez-Navarro, E. Sebastian, O. Cazalla and M.J. De La Torre, Eur. J. Miner., 13, 621-634 (2001).

23. M.F. La Russa, G. Barone, P. Mazzoleni, A. Pezzino, V. Crupi and D. Majolino, Appl. Phys., A 92, 187 (2008).

24. R.G. Milkey, Am. Mineral., 45, 990 (1960).

25. A. Issi, Ceramics International, 38 (3), 2375-2380 (2012). M.I. Carretero, M. Dondi, B. Fabbri, M. Raimondo, The influence of shaping and firing technology on ceramic properties of calcareous and non-calcareous illitic-chloritic clays, Appl. Clay Sci. 20 (2002) 301-306 